¡Acaso esta pasión de ver, doblemente simbolizada en la historia bíblica de la mujer de Loth, nos esté llevando nuevamente al término de las Ciudades Malditas! Y he ahí que cual una fruta reluciente y de sabor eternamente desconocido, el sexo, el Dios-Sexo, es adorado a plena luz como el signo magnífico de la imponderable necesidad de ver.- J os É $M$ ANUEL SÁ NCHEZ.

\title{
París y el centenario del romanticismo
}

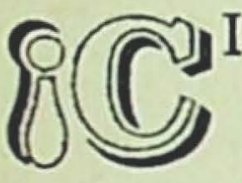

IEN años de romanticismo! Es bastante. París conmemora la historia de lo que ha sido su vida y su savia durante tan largo tiempo. Su bruma, sus flechas y sus aguas hablan hoy de ese "mal del siglo» que se representaba con un lago de fondo, un árbol inclinado y un joven meditabundo.

¿Qué es preciso entender por la palabra romanticismo? Un arte en que la imaginación y la sensibilidad predominan sobre toda otra facultad del espíritu, es la definición más acertada. En un sentido más vasto: vida adaptable «au roman». El romanticismo pasó como una avalancha invadiéndolo todo: música, literatura, política, poesía. Una revolución tan grande sólo la verán los siglos en el movimiento obrero que ha cambiado y cambiará las raíces mismas del hombre. Hoy existe en determinados medios y países una ideología marxista que invade el total de los campos espirituales y materiales. Ahí no se juzga a los artistas sino desde el punto de vista de clase: Proust, Gide, Paul Valéry son sólo los representantes de una burguesía ociosa y corrompida.

Esta cruz negra sobre el romanticismo y sus derivados, tomándolo en un sentido de exaltación del más allá, nos parece difícil concebirla. Hoy más que nunca el hombre busca la belleza abstracta, la combinación de imágenes y líneas que lleven a la irrealidad. El mundo ha dejado de ser una representación gráfica y se pretende fijar lo desconocido, la emoción de lo inexistente, la armonía de la desarmonía. Esfuerzos estériles de una sociedad en decadencia traducen los de mañana que miran al hombre que sufre, que lucha y que trabaja.

¿Esta tragedia del individualismo dará paso a un arte anónimo, como el gótico-religioso? Eso lo dirán y lo verán los si- 
glos. Hoy sólo nos cabe constatar que el derecho a la pasión que lo excusa todo, cantado por los románticos, es hoy en ciertos países como la Rusia soviética no un atenuante sino causa agravante en caso criminal.

Un número sobresaliente del programa ha sido la exposición organizada por la Biblioteca Nacional en la elegante sala Mazarino. Documentada y catalogada con gran claridad ella es en conjunto una manifestación de la especial inteligencia que tienen Jos franceses para todo lo que signifique presentación. En pequeñas vitrinas separadas están ahí los que podríamos llamar escalones consecutivos del gran movimiento. Comenzamos por las que contienen las primeras influencias extranjeras: Osiann. Poesías gaélicas de Macpherson, traducidas por Le Tourneur. Ejemplar de Napoleón I, que gustaba, como todos sus contemporáneos, de este hábil arreglo de cantos populares escoceses. Les Souffrances du jeune Werther, traducida al francés en 1776, y que es tal vez de todas las obras derivadas de la Nouvelle Heloìse la que ha dado al amor un color más romántico. Les nuits de Young, traducidas del inglés por Le Tourneun; libro de éxito clamoroso. Se sabe que es de Inglaterra de donde partió en el siglo XVIII la gran corriente de sensibilidad que invadió primero a Alemania y después a Francia, aportando ese gusto de lo fantástico y macabro, característico de un cierto aspecto del romanticismo. Otelo de Shakespeare, traducido por J. F. Ducis. El amor apasionado, los celos violentos, el desenvolvimiento patético de una pasión salvaje, el color exótico, el desprecio de las reglas de Aristóteles, todo contribuyó al éxito de esta pieza que tuvo en Francia una suerte igual a Hamlet, Macbeth y el Rey Lear. Voltaire lo trató de loco, y Rivarol y La Harpe pensaban más o menos como él, pero el actor Garrick, muy a la moda, consiguió popularizarlo, representando en 1751 fragmentos de Hamlet en los salones y haciendo llorar a los espectadores por la suerte de los Amantes de Verona, del Rey Lear, errante en medio de los bosques y por el destrozado corazón de Ofelia. L'Enfer, traducido por Rivarol, espiritual demoledor al cual la Revolución alejó de Francia, hecho que lo indujo a buscar los orígenes del poder político y los fundamentos del orden social. Y así este implacable burlón concibió la traducción de la terrible sátira al poder que es $E l$ Infierno. Rivarol, que murió en Berlín en 1801, fué uno de los pocos franceses que conoció en esa época La Divina Comedia. El está muy lejos de la ironía de Voltaire y de la ignorancia respetuosa de Chateaubriand. Su entusiasmo, lleno de reflexión, preparó mucho tiempo antes la reha- 
bilitación romántica del gran poeta italiano. Clarisa Harlowe, de Richardson, que conquistó todas las almas sensibles. Así, cuando Diderot en el delirio de su entusiasmo escribió el Elogio de Richardson no hizo sino decir con elocuencia cuanto pensaban los franceses.

Jamás se ha hecho en ninguna lengua una novela igual a Clarisa Harlowe, ni nada que se le aproxime-decía Jean Jacques Rousseau.

Más tarde aparece Byron cuya poesía inflamada, profundamente personal, creó las epopeyas líricas del peregrinaje de Childe Harold, de Giaour, de La novia de Abydos, del Corscrio y de Lara.

Según los historiadores literarios la protesta contra la imitación clásica comenzó en Francia en el siglo XVII, por la Querella entre antiguos y modernos. Ya Fontenelle, Perrault y La Motte le habían dado rudos golpes a la tragedia clásica, pero el verdadero demoledor de las reglas sobre las cuales reposaba es Diderot, el que se alza contra los preceptos de Aristóteles y de Horacio. Las tragedias son a sus ojos artificiales y falsas, contrarias a la naturaleza y a la verdad. La acción inverosímil, el lenguaje ampuloso y declamatorio, los trajes ridículos, la decoración nula. El poeta deberá tomar sus temas en la vida doméstica y creará la tragedia burguesa, en la que la prosa sustituirá al verso. Pero Diderot confundía muy a menudo la naturaleza con un realismo pueril y su sensibibilidad siempre en efusión le lanzaba a un género llorado y ridículo. Y fracasó en sus obras Padre de Familia e Hijo Natural. Fueron precisas otras influencias, más fuertes y profundas, para la reacción contra el clasicismo, que no estaba sino en gérmenes a mediados del siglo XVIII.

Estas influencias fueron, como se sabe, Chateaubriand y Madame Staël que representan el segundo período del romanticismo francés.

Napoleón, que buscaba a los poetas como accesorios a su gloria sólo consiguió alejarlos y contribuir así a la gran renovación literaria que se preparaba. Fué allá en su destierro a Alemania donde Mme. Staël entrevió la literatura del porvenir. Su entusiasmo por este país contribuyó a atraer las miradas al otro lado del Rhin y a trasplantar a Francia algo del ensueño y lirismo alemán. Estos libros fueron secuestrados durante largo tiempo por la policía imperial, y la poesía clásica pasó, de hecho, a representar el pensamiento oficial.

Pero en 1820 aparecen las Meditaciones de Lamartine y no 
hubo ya diques que oponer al mar. Dos años después de las Meditaciones son las Odas de Víctor Hugo, y junto a este nombre se agrupan Alfredo de Vigny, Emile Deschamps, Delfina Gay (la futura Madame de Girardin) y muchos otros que representan los héroes de la gran batalla romántica. Al ardor de los principios literarios se unen los políticos, pero, por extraña ideología, los románticos eran realistas y los clásicos liberales. Los que predicaban la libertad en el arte eran absolutistas en política. El enardecimiento de la pelea llevó a los académicos a cambiar la palabra romántico por la de alienado. Es en este momento cuando Víctor Hugo lanza su célebre manifiesto que es el Prefacio de Cronwell (1827). En él hay, a grandes trazos, una historia de la poesía que dice así:

La poesía tiene tres edades: cada una corresponde a una época de la sociedad: la oda, la epopeya, el drama. Los tiempos primitivos son líricos, los antiguos épicos, los modernos dramáticos. El drama es la poesía completa y su carácter es lo real. Lo real resulta de la combinación natural de dos tipos, lo sublime y lo grotesco, que se cruzan en el drama como se cruzan en la vida y en la creación. Porque la poesía verdadera, la poesía completa, está en la armonía de los contrastes... Todo lo que está en la naturaleza está en el arte.

Esta expresión de la vida integral, de la vuelta a lo verdadero, fueron las fórmulas de la escuela nueva, cuyo cenáculo eran los salones de Charles Nodier, bibliotecario del Arsenal.

$\mathrm{Y}$ es aún a Víctor Hugo a quien corresponde ganar la batalla definitiva con su dramático Hernani.

Sería difícil-escribe Gautier cuarenta y cuatro años más tarde-describir el efecto que producían en el auditorio esos versos tan singulares, $\tan$ fuertes y varoniles, de una forma tan extraña, de un aire tan corneliano y shakesperiano a la vez. Dos sistemas, dos partidos, dos ejércitos, y aun, no es exageración decirlo, dos civilizaciones, estaban ahí presentes odiándose cordialmente como se odia en el campo literario. ¿Qué ruido!, iqué gritos!, iqué silbidos!, ¡qué huracán de bravos!, iqué torrentes de aplausos! Los jefes de partido se injuriaban como los héroes de Homero... Para esta generación Hernani ha sido lo que fué el Cid para los contemporáneos de Corneille. Todo joven valiente, poético y enamorado sintió el soplo... Y el encanto dura todavía para los cautivos.

$Y$ después ya fué el reinado pleno, incontestable, indiscutido. La apoteosis del yo, en sus dudas, sus sufrimientos, sus alegrías y sus exaltaciones. La realización del ser íntimo como síntesis del universo, hasta el momento en que apareció el naturalismo burlándose de estos señores que anteponían a todo su caso personal. Y hoy que la vida sentimental es fácil, frívola y amable, y que ya nadie llora por su amor ni por su da- 
ma, el público de París se inclina ante esta fila de cadáveres. románticos como ante spécimens curiosos de museo, cortados todos los hilos, aún de la más lejana conexión.-M A R T A VE R G A R A.

\section{Orientaciones del arquitecto}

- 1 N 1928, en el Castillo de La Sarraz, Suiza, celebróse un Congreso Internacional de Arquitectos, en el que fueron echadas las bases de una agrupación internacional y se estableció un programa de acción común. La asamblea publicó un manifiesto que exponía el papel del arquitecto en la sociedad y los diversos problemas que le conciernen. Veinticuatro arquitectos firmaron la siguiente declaración:

Los arquitectos sucritos, representantes de grupos nacionales de arquitectos modernos, afirman su unidad de criterio sobre las concepciones fundamentales de la Arquitectura y sobre sus deberes profesionales hacia la sociedad. Insisten particularmente en el hecho de que 'construir ? es una actividad elemental del hombre, actividad que está íntimamente ligada a la evolución y al desarrollo de la vida humana. La tarea de los arquitectos consiste en ponerse de acuı rdo con la orientación de su época y sus obras deben expresar el espíritu de su tiempo. Rehusan, por consiguiente, emplear en su método de trabajo los principios que han podido animar a las sociedades pasadas, y afirman, por lo contrario, la necesidad de una concepción nueva de la Arquitectura, que satisfaga las exigencias espirituales, intelectuales y materiales de la vida presente. Conscientes de las transformaciones profundas aportadas a la estructura social por el maquinismo, reconocen que la transformación del orden y de la vida social entraña fatalmente la correspondiente transformación del fenómeno arquitectural.

Extraña que los arquitectos, cuyo papel es construir, pretendan explicarnos por medio del lenguaje las razones que determinan su obra, y más aún nos ha de extrañar, si sus declaraciones, como las trascritas, salen de la zona artística y abarcan campos que hasta ahora han permanecido indiferentes para ellos. Porque, aunque no es la primera vez que esto sucede, ya que muchos arquitectos han expuesto en diversa forma las razones de su obra o el concepto que tenían de su profesión y del ejercicio de ella, es la primera vez, en cambio, que el arquitecto abandona su actitud meramente artística, meramente creadora, y se traslada al campo de las realidades 